\title{
Uitdagingen bij de ontwikkeling van AIDS-vaccins
}

\author{
A. de Goede
}

De AIDS-pandemie is nog steeds niet onder controle. Wereldwijd waren in 2007 ongeveer 33.2 miljoen mensen HIV geïnfecteerd, werden 2.5 miljoen mensen nieuw besmet en zijn 2.1 miljoen mensen overleden aan $\operatorname{AIDS}^{1}$.

Antiretrovirale middelen dragen bij aan de bestrijding van de verspreiding van HIV, maar om de pandemie een halt toe te roepen is een veilig, werkzaam, goedkoop, gemakkelijk bruikbaar en wereldwijd verkrijgbaar middel nodig. Een vaccin kan idealiter aan deze vereisten voldoen $^{2,3,4}$. Na meer dan 20 jaar onderzoek is er echter nog geen doorbraak in de ontwikkeling van een dergelijk vaccin. Hoe komt dit?

Tegen verschillende virussen zijn succesvolle vaccins ontwikkeld met behulp van virale 'subunits' of geïnactiveerd virus. De opwekking van antilichamen met deze vaccins heeft onvoldoende effect op HIV. Cellulaire immuniteit kan de virusreplicatie gedurende korte of soms langere tijd onderdrukken. Afwezigheid van cellulaire immuniteit leidt echter tot snelle progressie van de HIV-infectie tot AIDS. Vaccinatie met levend verzwakt virus geeft naast humorale ook cellulaire immuniteit. Omdat een HIV-vaccin mogelijk een chronische infectie kan veroorzaken, wordt deze strategie als te riskant beschouwd. Zelfs als het lukt om een goede cellulaire immuniteit op te wekken, zal het moeilijk zijn HIV volledig te elimineren omdat het virus zich in het DNA van de gastheercel nestelt. Hierdoor ontstaat een permanent reservoir voor virusproductie. Daarnaast is het virus uiterst variabel en ontsnapt het telkens weer aan de afweer door nieuwe mutaties ${ }^{4}$. Een ander belangrijk obstakel bij de ontwikkeling van een vaccin is het ontbreken van een betrouwbaar diermodel ${ }^{4}$.
Het belangrijkste doel bij de ontwikkeling van een vaccin is profylaxe van een HIV-infectie. Berkley en Koff benadrukken het belang van neutraliserende antistoffen (humorale immuniteit) voor een dergelijk vaccin ${ }^{2}$. Inmiddels wordt ook onderzoek gedaan naar therapeutische vaccins. Deze vaccins zijn gericht op verlaging van het aantal virusdeeltjes bij HIV-geïnfecteerden. Dit vertraagt de progressie naar AIDS en vermindert de transmissie van $\mathrm{HIV}^{2}$.Voor therapeutische vaccins is juist de cellulaire immuniteit, waarbij cytotoxische T- lymfocyten een grote rol spelen, belangrijk ${ }^{3,4}$.

Zowel voor profylactische als voor therapeutische vaccinatie worden verschillende vaccins klinisch onderzocht. Deze zijn gebaseerd op HIV-eiwitten of peptiden of op HIV-genen die als naakt DNA of met vectoren worden toegediend ${ }^{2,3}$.

Om de zoektocht naar een vaccin te bespoedigen is financiële en politieke ondersteuning van onderzoekers, kleine biotech bedrijfjes en studiecohorten in ontwikkelingslanden nodig. In combinatie met een rationele aanpak van ontwikkeling van een vaccin en gecoördineerd wetenschappelijk onderzoek biedt dit de grootste kans op een veilig en werkzaam AIDSvaccin ${ }^{2}$.

Belangenverstrengeling: geen.

\section{Literatuur}

UNAIDS/WHO. AIDS epidemic update: November 2007.

Berkley SF, Koff WC. Scientific and policy challenges to development of an AIDS vaccine. Lancet 2007; 370: 94-101.

Johnston MI, Fauci AS. An HIV vaccine-evolving concepts. N Engl J Med 2007; 356: 2073-81.

Tonks A. Quest for the AIDS vaccine. BMJ 2007; 334: 1346-48. 